\title{
GAMBARAN KADAR GULA SESAAT PADA DEWASA MUDA USIA 20-30 TAHUN DENGAN INDEKS MASSA TUBUH (IMT) $\geq 23 \mathrm{~kg} / \mathrm{m}^{2}$
}

\author{
${ }^{1}$ Juandi Kasengke \\ ${ }^{2}$ Youla A. Assa \\ ${ }^{2}$ Michaela E. Paruntu
}

\author{
${ }^{1}$ Kandidat Skripsi Fakultas Kedokteran Universitas Sam RatulangiManado \\ ${ }^{2}$ Bagian Biokimia Fakultas Kedokteran Universitas Sam RatulangiManado \\ Email: juandikasengke@yahoo.com
}

\begin{abstract}
Hyperglycemia is a state of elevated level of blood sugar in human body that exceeds normal level. The causes are not known yet for sure but it is often associated with insulin insufficiency and predisposition factors such as genetic, age, and obesity. Prolonged hyperglycemia may lead to the development of diabetes mellitus and as a risk factor of other metabolic diseases. Morbidity in hyperglycemia is increased along with the age and body weight. This study aimed to obtain the random blood glucose level among young adults aged 20-30 years with a body mass index (BMI) $\geq 23 \mathrm{~kg} / \mathrm{m}^{2}$. This was a descriptive study. The population consisted of 20 to 39 years old young adults with body mass index (BMI) $\geq 23 \mathrm{~kg} / \mathrm{m}^{2}$ who lived in the working area Community Health Center in Beo, Talaud. Data consisted of BMI measurements and random blood glucose levels by using stick device. The results showed that of 30 respondents with BMI $\geq 23 \mathrm{~kg} / \mathrm{m}^{2}$, there was 1 respondent (3.33\%) had hyperglycemia meanwhile the other 29 respondents (96.6\%) had normal blood glucose level. Conclusion: In this study, the random blood glucose level among young adults aged 20-30 years with body mass index (BMI) $\geq 23 \mathrm{~kg} / \mathrm{m}^{2}$ were in normal range.
\end{abstract}

Keywords: random plasma glucose level, $20-30$ years old young adults, BMI $\geq 3 \mathrm{~kg} / \mathrm{m}^{2}$

\begin{abstract}
Abstrak: Hiperglikemia adalah keadaan peningkatan kadar glukosa darah dalam tubuh seseorang yang melebihi kadar normal. Penyebab belum diketahui pasti tetapi sering dihubungkan dengan kurangnya insulin dan fator predisposisi yaitu genetik, umur, dan obesitas. Hiperglikemia yang tidak dikontrol secara terus menerus akan berkembang menjadi penyakit diabetes mellitus dan merupakan faktor risiko untuk penyakit metabolik lainnya. Angka morbiditas pada hiperglikemia juga meningkat seiring bertambahnya umur dan berat badan. Penelitian ini bertujuan untuk mengetahui gambaran kadar glukosa darah pada dewasa muda yang berusia 20-30 tahun dengan Indeks Massa Tubuh (IMT) $\geq 23 \mathrm{~kg} / \mathrm{m}^{2}$. Penelitian ini menggunakan metode deskriptif. Populasi ialah dewasa muda berusia 20-30 tahun dengan IMT $\geq 23 \mathrm{~kg} / \mathrm{m}^{2}$ yang tinggal di wilayah Puskesmas Beo Kecamatan Beo Kabupaten Kepulauan Talaud. Data diperoleh dengan pengukuran IMT dan pemeriksaan kadar glukosa darah sesaat dengan menggunakan alat stick. Terdapat 30 responden dengan IMT $\geq 23 \mathrm{~kg} / \mathrm{m}^{2}$ dimana 1 orang (3.33\%) yang mengalami hiperglikemia dan 29 orang (96.6\%) dengan kadar glukosa darah dalam batas normal. Simpulan: Sebagian besar dewasa muda usia 20-30 tahun dengan IMT $\geq 23 \mathrm{~kg} / \mathrm{m}^{2}$ mempunyai kadar glukosa darah sesaat normal.
\end{abstract}

Kata kunci: glukosa darah sesaat, dewasa muda usia 20-30 tahun, IMT $\geq 23 \mathrm{~kg} / \mathrm{m}^{2}$

Gula darah terdiri dari glukosa, fruktosa, dan galaktosa. Glukosa merupakan monosakarida yang paling dominan, sedangkan fruktosa akan meningkat pada diet buah yang banyak, dan galaktosa darah akan meningkat pada saat hamil dan laktasi.
Sebagian besar karbohidrat yang dapat dicerna di dalam makanan akhirnya akan membentuk glukosa, yang kemudian akan dialirkan kedalam darah, dan gula lain akan dirubah menjadi glukosa di hati. ${ }^{1}$

Glukosa juga dicadangkan dalam 
bentuk glikogen. Jika asupannya banyak, glukosa akan diubah sebagai trigliserida pada jaringan adiposa, sebagai sumber gliserida-gliserol, dan mungkin mempunyai peran di dalam mempertahankan kadar intermediate pada siklus asam sitrat di banyak jaringan tubuh. ${ }^{2}$

Glukosa merupakan satu satunya bahan bakar yang memasok energi bagi otot rangka pada keadaan anaerob. Unsur ini merupakan prekursor gula susu (laktosa) di kelenjar payudara dan secara aktif diambil oleh janin. Glukosa juga merupakan prekursor untuk sintesis bermacam-macam senyawa khusus, misalnya laktosa, antigen, permukaan sel, nukleotida, atau glikosaminoglikan. Beberapa jaringan dalam tubuh, misalnya otak dan sel darah merah, bergantung pada glukosa untuk memperoleh energi. Dalam jangka panjang, sebagian besar jaringan juga memerlukan glukosa untuk fungsi lain misalnya membentuk gugus ribosa pada nukleotida atau bagian karbohidrat pada glikoprotein. ${ }^{3}$

Kadar gula darah dipengaruhi oleh pola makan. Kadar glukosa darah seseorang setelah makan akan berbeda dengan kadar glukosa sebelum makan, atau kadar glukosa seseorang yang sedang puasa. Setelah makan makanan yang mengandung karbohidrat, kadar glukosa darah meningkat. Sebagian glukosa dalam makanan diubah dalam hati sebagai glikogen. Setelah 2 jam atau 3 jam berpuasa, glikogen ini mulai diuraikan oleh proses glikogenolisis, dan glukosa yang terbentuk dilepaskan ke dalam darah. Seiring dengan penurunan simpanan glikogen, juga terjadi penguraian triasilgliserol di jaringan adiposa, yang menghasilkan asam lemak sebagai bahan bakar alternatifdan gliserol untuk sintesis glukosa melalui glukoneogenesis. Asam amino juga dilepaskan dari otot untuk berfungsi sebagai prekursor glukoneogenesis. Setelah puasa satu malam, kadar glukosa darah dipertahankan baik oleh glikogenolisis maupun glukoneogenesis. Setelah 30 jam berpuasa, simpanan glikogen hati habis. Sesudah itu, glukoneogenesis merupakan satu-satunya sumber glukosa darah. $^{4}$
Setelah penyerapan makanan, kadar glukosa darah pada manusia berkisar antara 4,5-5,5 mM. Setelah mengonsumsi makanan yang mengandung karbohidrat, kadar tersebut dapat naik hingga 6,5-7,2 mM. Di saat puasa, kadar glukosa darah akan turun menjadi 3,3-3,9 mM. Penurunan mendadak kadar glukosa darah akan menimbulkan serangan konvulsi, seperti terlihat pada keadaan overdosis insulin, karena ketergantungan otak secara langsung pada pasokan glukosa. ${ }^{5}$

Pola makan yang tidak teratur akan menyebabkan ketidakseimbangan antara energi yang dibutuhkan oleh tubuh dengan makanan sebagai penghasil energi. Hal ini yang membuat seseorang dapat menderita obesitas. Di Indonesia khususnya, cara pemantauan dan batasan berat badan normal orang dewasa digunakan cara perhitungan berat badan normal berdasarkan Indeks Massa Tubuh (IMT). Penggunaan IMT ini hanya berlaku untuk orang dewasa yang berumur di atas 18 tahun, sedangkan IMT yang diterapkan pada bayi, anak, remaja, ibu hamil dan olahragawan memakai kriteria standard yang lain. ${ }^{6}$

Perubahan gaya hidup terutama di kota besar, menyebabkan meningkatnya prevalensi penyakit degeneratif, seperti penyakit Diabetes Melitus (DM), namun data epidemiologi di Indonesia masih belum banyak. Hal ini disebabkan penelitian epidemiologi sangat mahal biayanya. ${ }^{7}$

Diabetes Melitus (DM) selama ini dipahami sebagai penyakit keturunan atau genetik. Artinya, bila orang tuanya pengidap DM maka kemungkinan anakanaknya juga akan mengidap DM. Faktor turunan atau genetik saja tidak cukup dan diperlukan faktor lain yang disebut faktor risiko atau faktor pencetus. Faktor risiko untuk terjadi DM tipe-1 dan DM tipe-2 berbeda. $^{8}$

\section{METODE PENELITIAN}

Penelitian ini merupakan penelitian survei deskriptif dengan rancangan potong lintang. Sampel penelitian berjumlah 30 orang responden berdasarkan metode pengambilan sampel purposive sampling, 
yaitu memilih sampel yang memenuhi kriteria tertentu: Masyarakat di Puskesmas Beo Kecamatan Beo pada bulan Februari 2013 yang berusia 20-30 tahun dengan IMT $\geq 23,0 \mathrm{~kg} / \mathrm{m}^{2}$. Pada dewasa muda usia minimal 20 tahun maksimal 30 tahun, dan bersedia menjadi responden.

Pengambilan sampel dilakukan dengan menggunakan kuesioner untuk mendapatkan sampel yang sesuai dengan kriteria, kemudian dilakukan pengukuran berat badan dan tinggi badan setelah sampel menandatangani informed consent.

Pengukuran IMT menggunakan rumus berat badan dalam kilogram (kg) dibagi tinggi dalam meter kuadrat $\left(\mathrm{m}^{2}\right)$ dan penilaian kadar glukosa darah sesaat dilakukan dengan pengambilan darah pada vena mediana cubiti dengan tidak memandang waktu. Dalam penelitian ini klasifikasi IMT menggunakan kriteria World Health Organization (WHO) untuk Asia-Pasifik ${ }^{6}$ dan penilaian kadar glukosa darah puasa menggunakan kriteria menurut Perkeni tahun 2006. ${ }^{7}$

\section{HASIL PENELITIAN}

Berdasarkan jenis kelamin diperoleh data bahwa dari 30 orang responden ditemukan 9 orang (30\%) berjenis kelamin laki-laki dan 21 orang (70\%) berjenis kelamin perempuan (Tabel 1).

Tabel 1. Distribusi Responden Berdasarkan Jenis Kelamin

\begin{tabular}{ccc}
\hline Jenis Kelamin & $\mathrm{n}$ & $\%$ \\
\hline Laki-laki & 9 & 30 \\
Perempuan & 21 & 70 \\
Jumlah & 30 & 100 \\
\hline
\end{tabular}

Berdasarkan umur diperoleh data bahwa dari 30 orang responden ditemukan 12 orang (40\%) pada golongan 20-25 tahun dan 18 orang (60\%) pada golongan 26-30 tahun. (Tabel 2).

Dari 30 orang responden ditemukan 14 orang $(46,66 \%)$ preobesitas, 16 orang (53,33\%) dengan obesitas tingkat I, dan tidak ditemukan obesitas tingkat II pada penelitian ini. (Tabel 3).

Tabel 2. Distribusi Responden Berdasarkan Umur

\begin{tabular}{ccc}
\hline Umur & $\mathrm{n}$ & $\%$ \\
\hline $20-25$ & 12 & 40 \\
$26-30$ & 18 & 60 \\
Jumlah & 30 & 100 \\
\hline
\end{tabular}

Tabel 3. Distribusi Responden Berdasarkan Berat Badan Menurut Indeks Massa Tubuh

\begin{tabular}{ccc}
\hline $\begin{array}{c}\text { Klasifikasi } \\
\text { Berat Badan Berlebih }\end{array}$ & $\mathrm{n}$ & $\%$ \\
\hline Preobesitas $\left(23,0-24,9 \mathrm{~kg} / \mathrm{m}^{2}\right)$ & 14 & 46,66 \\
Obesitas I $\left(25,0-29,9 \mathrm{~kg} / \mathrm{m}^{2}\right)$ & 16 & 53,33 \\
Obesitas II $\left(>30,0 \mathrm{~kg} / \mathrm{m}^{2}\right)$ & - & - \\
$\quad$ Jumlah & 30 & 100 \\
\hline
\end{tabular}

Dari 30 orang responden ditemukan 29 orang (96,66\%) yang memiliki kadar glukosa darah sesaat yang normal dan 1 orang (3,33\%) yang memiliki kadar glukosa darah sesaat yang tinggi. (Tabel 2.4)

Tabel 4. Distribusi Responden Berdasarkan Kadar Glukosa Darah Sesaat

\begin{tabular}{|c|c|c|}
\hline Kadar GDS & $\mathrm{n}$ & $\%$ \\
\hline Normal & 29 & 96,66 \\
Pre Diabetes & 1 & 3,33 \\
Diabetes & - & - \\
\hline Jumlah & 30 & 100 \\
\hline
\end{tabular}

Berdasarkan hasil penelitian kadar gula darah sesaat diperoleh data bahwa pada golongan umur 20-25 tahun terdapat 12 orang (40\%) yang memiliki kadar GDS normal dan tidak ditemukan kadar GDS yang tinggi. Sedangkan pada golongan umur 25-30 tahun terdapat 17 orang (56,66\%) yang memiliki kadar GDS normal dan 1 orang (3,33\%) yang memiliki kadar GDS tinggi.

Hasil penelitian kadar gula darah sesaat diperoleh juga data bahwa pada jenis kelamin laki-laki terdapat 9 orang (30\%) yang memiliki kadar GDS normal dan tidak ditemukan kadar GDS yang tinggi. Sedangkan pada jenis kelamin perempuan 
terdapat 20 orang (66,66\%) yang memiliki kadar GDS normal dan 1 orang (3,33\%) yang memiliki kadar GDS tinggi (Gambar. 4.)

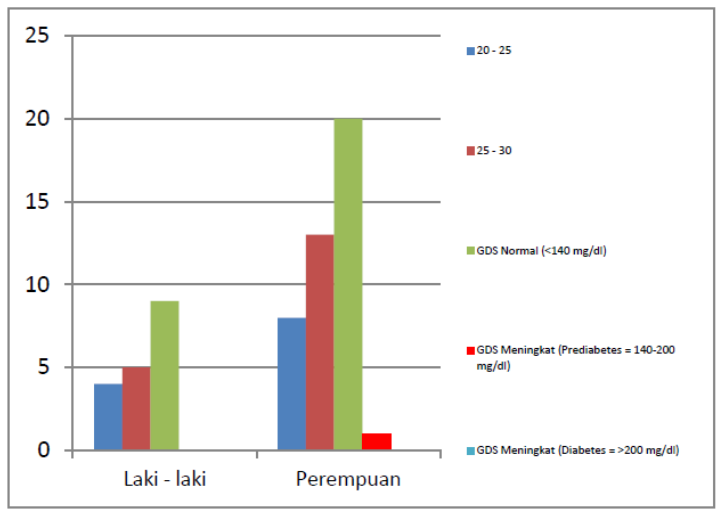

Gambar 4. Diagram Distribusi Jenis Kelamin Responden Kadar Gula Darah Sesaat

\section{BAHASAN}

Pada penelitian ini diambil 30 responden dari golongan umur 20-30 tahun dengan Indeks Massa Tubuh $\geq 23,0 \mathrm{~kg} / \mathrm{m}^{2}$. Jenis kelamin perempuan adalah yang terbanyak dalam penelitian ini yaitu 21 orang (70\%) dan dari 30 orang yang memiliki berat badan lebih ini ternyata kelompok obesitas I merupakan kelompok yang paling banyak ditemukan yaitu dengan 16 orang (53,33\%) bila dibandingkan dengan preobesitas (overweight) dengan 14 orang (46,66\%), dan tidak ditemukan obesitas tingkat II pada penelitian ini. Hal ini perlu diwaspadai karena saat ini obesitas merupakan masalah kesehatan kompleks yang membutuhkan perhatian khusus dan telah dianggap sebagai masalah epidemiologi global. Prevalensi obesitas terusmenerus meningkat dari tahun ke tahun terlebih pada beberapa decade terakhir ini baik di Negara industri maupun di Negara berkembang termasuk Indonesia. Obesitas memegang peranan penting dalam patofisiologi terjadinya penyakit metabolik dan kardiovaskuler. Penyakit metabolik ini antara lain meliputi gangguan toleransi glukosa, diabetes mellitus, hipertensi, resistensi insulin, dan dislipedimia; walaupun sampai saat ini masih sulit mengetahui secara jelas bagaimana sebenarnya hubungan kausal antara penyakit dan lemak tubuh. ${ }^{9}$

Hiperglikemia adalah keadaan dimana kadar glukosa darah sesaat $140-200 \mathrm{mg} / \mathrm{dL}$. Harus dicurigai adanya diabetes mellitus apabila kadar glukosa plasma vena yang diambil tanpa memandang kapan saat makan terakhir (sampel acak/sesaat) $\geq$ $140 \mathrm{mg} / \mathrm{dL}$. Setelah makan jelas kadar glukosa darah meningkat dari kadar puasa sekitar 80-100mg/dL ke kadar sekitar 120$140 \mathrm{mg} / \mathrm{dL}$, terutama pada penderita yang memperlihatkan tanda dan gejala klasik dari hiperglikemia kronik (polidipsia, poliuria, penglihatan kabur, nyeri kepala, penurunan berat badan yang cepat, kadangkadang disertai mual dan muntah). ${ }^{10}$

Pada penelitian ini didapat 1 orang $(33,3 \%)$ dari 30 responden yang mengalami hiperglikemia. Walaupun masih berusia 20-30 tahun dengan berat badan lebih tapi dalam penelitian ini sebagian besar 29 orang (96,6\%) kadar glukosa darah dalam keadaan normal dan tidak terganggu. Dari hasil penelitian ini dapat dilihat bahwa sebagian besar responden penelitian yang tinggal di Kecamatan Beo khususnya wilayah Puskesmas Beo memiliki kadar glukosa darah sesaat normal dan hanya sebagian kecil saja yang mengalami peningkatan kadar glukosa darah sesaat. Untuk itu perlu dianjurkan supaya dilanjutkan dengan pemeriksaan lebih lanjut misalnya pemeriksaan glukosa darah puasa atau uji toleransi glukosa untuk mendapatkan data yang lebih akurat.

Dalam penelitian ini responden dengan berat badan lebih tidak selalu diikuti oleh peningkatan kadar glukosa darah sesaat. Hal ini membuktikan bahwa kadar glukosa darah tidak hanya ditentukan oleh satu faktor saja tetapi berbagai macam faktor antara lain pola makan, olahraga, gaya hidup, lingkungan, genetic dan sosial ekonomi. Pengaturan pola makan dengan diet yang baik, olahraga yang teratur, dan gaya hidup yang baik merupakan cara yang cukup efektif untuk menjaga kadar glukosa darah pada batas normal. ${ }^{11}$ 
Perlunya penambahan jumlah sampel dan populasi penelitian untuk meneliti faktor-faktor yang berhubungan dengan kadar glukosa darah. Hal inilah yang dibutuhkan untuk memastikan apakah benar adanya hubungan antara variabel tingginya kadar glukosa darah dengan variabel lainnya seperti pola makan, gaya hidup, dan status ekonomi di Kecamatan Beo khususnya di wilayah Puskesmas Beo.

\section{SIMPULAN}

Berdasarkan hasil penelitian gambaran kadar glukosa darah sesaat pada dewasa muda usia 20-30 tahun dengan IMT $\geq 23,0$ $\mathrm{kg} / \mathrm{m}^{2}$ di Puskesmas Beo Kecamatan Beo, dapat disimpulkan bahwa sebagian besar dewasa muda berusia 20-30 tahun yang berdomisili di Kecamatan Beo memiliki kadar gula darah sesaat normal

\section{UCAPAN TERIMAKASIH}

Ucapan terima kasih disampaikan pada masyarakat di Puskesmas Beo Kecamatan Beo yang telah bersedia menjadi sampel penelitian, Puskesmas Beo Kecamatan Beo yang telah membantu pemeriksaan Laboratorium pada penelitian ini, dan pada semua pihak yang baik secara langsung maupun tidak langsung telah menumbuhkan ide atau gagasan dalam pemikiran penulis sehingga dapat menyelesaikan artikel ini.

\section{DAFTAR PUSTAKA}

1. Murray RK, Granner DK, Mayes PA, Rodwell VW. Bioenergetika dan Metabolisme Karbohidrat serta Lipid. Bani AP, Sikumbang TMN, editor bahasa Indonesia. Biokimia Harper. Edisi ke-25. Hartono A, ahli bahasa. Jakarta: EGC, 2003; p. 114-282.

2. Marks DB, Marks AD, Smith CM. Metabolisme Karbohidrat. Suyono J, Sadikia V, Mandera LI, editor bahasa Indonesia. Biokimia Kedokteran Dasar,
Sebuah Pendekatan Klinis. Pendit BU, ahli bahasa Indonesia. Jakarta: Buku Kedokteran EGC, 2000; p. 381-462.

3. Murray RK, Granner DK, Mayes PA, Rodwell VW. Glukoneogenesis dan Pengontrolan Kadar Glukosa Darah. Bani AP, Sikumbang TMN, editor bahasa Indonesia. Biokimia Harper. Edisi ke-25. Hartono A, ahli bahasa. Jakarta: EGC, 2003; p. 25-206.

4. Marks DB, Marks AD, Smith CM. Metabolisme Karbohidrat. Suyono J, Sadikia V, Mandera LI, editor bahasa Indonesia. Biokimia Kedokteran Dasar, Sebuah Pendekatan Klinis. Pendit BU, ahli bahasa Indonesia. Jakarta: EGC, 2000; p. 381-422.

5. Murray RK, Granner DK, Mayes PA, Rodwell VW. Glukoneogenesis dan Pengontrolan Kadar Glukosa Darah. Bani AP, Sikumbang TMN, editor bahasa Indonesia. Biokimia Harper. Edisi ke-25. Hartono A, ahli bahasa. Jakarta: EGC, 2003; p. 25-206.

6. Utama H. Diabetes Melitus. Hidup Sehat Dengan Diabetes. Jakarta : Balai Penerbit FKUI, 2007; p. 1-10.

7. Supariasi IDN, Bakri B, Fajar I. Indeks Antropedi. Ester M, editor. Penilaian Status Gizi. Jakarta: EGC, 2001; p. 5662.

8. Murray RK, Granner DK, Mayes PA, Waspadji S, Sukardji K, Octarina M. Diabetes Melitus dan pengelolaannya. Pedoman Diet Diabetes Melitus. Jakarta: Balai Penerbit FKUI, 2009; p. 9-10.

9. Utama H. Diabetes Melitus. Hidup Sehat dengan Diabetes. Jakarta: Balai Penerbit FKUI, 2007; p. 21.

10. Sugondo S. Obesitas. In: Sudoyo AW, Setiyohadi B, Alwi I, Setiati S, editor. Ilmu Penyakit Dalam. Edisi ke-4. Jakarta: FKUI, 2006; p.1941-7.

11. Supariasi IDN, Bakri B, Fajar I. Antropometri Gizi. Ester M, editor. Penilaian Status Gizi. Jakarta: EGC, 2001; p. 86-87. 